https://doi.org/10.36910/6775-2410-6208-2021-6(16)-27

УДК 69.002.2-69.057.3

\title{
АДАПТАЦІЙНІ МОДЕЛІ ВАРІАНТНОГО ПРОЕКТУВАННЯ ТЕХНОЛОГІЙ ГНУЧКИХ МОДУЛЬНИХ ПРОМИСЛОВО- БУДІВЕЛЬНИХ СИСТЕМ
}

\author{
ADAPTIVE MODELS OF VARIANT DESIGN OF \\ TECHNOLOGIES OF FLEXIBLE MODULAR INDUSTRIAL AND \\ CONSTRUCTION SYSTEMS
}

Уваров П.Є., к.т.н., доцент, Білошицький М. В., к.т.н., доцент, Шпарбер М.Є., ст. викл., Піддубний С.В., ст. викл. (Східноукраїнський національний Університет імені Володимира Даля, м. Ссвєродонецьк)

Uvarov P.E., PhD., associate professor, Biloshytskiy M.V., PhD., associate professor, Shparber M.E., senior lecturer, Piddubnyi S.V., senior lecturer (Volodymyr Dahl East Ukrainian National University, Severodonetsk)

Стаття присвячена актуальним питанням розвитку організаційнотехнологічного проектування промислово-будівельних систем. Розглянуто особливості та адаптивність варіантного проектування гнучких модульних технологій промислово-будівельного виробництва, щзо відображають фактори інженерного забезпечення у завданнях обтрунтування ефективності та організачійно-економічної підготовки виробничтва проектів-об'єктів будівництва хімічних підприємств з урахуванням параметрів життєвого ијиклу їхнього розвитку.

The article is devoted to topical issues of development of organizational and technological design of industrial and building systems. Peculiarities and adaptability of variant design of flexible modular technologies of industrial and construction production are considered, which reflect factors of engineering support in tasks of substantiation of efficiency and organizational and economic preparation of production of projectsobjects of construction of chemical enterprises taking into account parameters of their life cycle. The analysis and assessment of the results of the application of modular technologies of complete-block, flow-combined and separate methods for the construction of industrial buildings of a new generation and options for organizing the manufacture of delivery and enlargement of blocks, which made it possible to evaluate the identified interdependencies between labor costs, duration and weight of blocks. Regression analysis was used to process the obtained systematized data. The quantitative values of the regression coefficients are obtained on the basis of the Gauss method (least squares method). Evaluation of the obtained dependencies by calculating regression coefficients, standard deviations, etc., as well as their assessment using the tabular 
values of Fisher's coefficients, confirmed the correctness of the hypothesis put forward. The constructed engineering nomograms make it possible to determine the labor costs and the duration of the installation of blocks, depending on the weight parameters of the blocks for various methods of their installation and options for organizing and forming blocks in relation to objects-representatives of chemical enterprises and industries. The choice of a rational option for flexible modular technology should be carried out according to the mini-max criterion: minimum labor costs for installation, testing and commissioning cycle of block-complete devices in the design position due to the maximum flow-combined organization of industrial and construction production methods, principles of targeted aggregation of technological processes, organizational structures and management functions.

Ключові слова: модульне проектування, модулі агрегованого обладнання, комплектно-блоковий монтаж, варіантне проектування, адаптивні моделі, технології прийняття рімень

Key words: modular design, modules of aggregated possession, complete-block installation, options for design, adaptive models, technologies of acceptance of solutions

Постановка проблеми. Розробка та впровадження у практику організаційно-технологічного проектування принципів адаптивних моделей на основі гнучкості промислово-будівельних технологій, що враховують сучасні вимоги варіантності та альтернативності, які використовують методи автоматизованого проектування гнучких промислово-будівельних модулів (ПБМ) та прийняття рішень щодо їх реалізації, системного моделювання та комбінації, $\epsilon$ актуальною проблемою у завданнях прийняття ефективних організаційнотехнологічних рішень $[1,2,4,7,8]$.

Мета роботи - узагальнення методів та засобів адаптаційних моделей варіантного проектування при формуванні гнучких модульних промислово-будівельних технологій, що забезпечують розвиток АСА інструментарію методів та засобів (аналізу - синтезу - адаптацій) для дослідження та прийняття організаційно-технологічних рішень характеристик інвестиційно-будівельної діяльності (ІБД) та експлуатації виробничих будівель нового покоління у комплектно-блочному виконанні (ВБНП-КБВ).

Виконаний комплексний аналіз виявив необхідність вирішення завдання кількісної та якісної оцінки рівня адаптивності та гнучкості моделей ВБНП-КБВ, промислово-будівельних технологій та методів організації зведення проєкта-об'єкту будівництва (П-ОБ).

Для оцінки здатності ВБНП-КБВ (будівельної та технологічної частини П-ОБ) до перетворень за часом та фазовим простором у повному життєвому циклі ІБД (модернізації, реконструкції, розширення та ліквідації), удосконалення методів організації та технології робіт та 
будівельних параметрів П-ОБ на стадії його експлуатації, а часто вже і на стадії будівництва - призначено критерій адаптивності.

Апаратом для обчислення даного критерію може бути інваріантний метод (незмінність величин за певних перетворень змінних).

Кількісно рівень гнучкості як інтегральну характеристику пропонується оцінювати коефіцієнтом гнучкості (технології зведення) К Кгт 3 використанням прийому кодування в двійкових числах із ранжуванням основних якісних показників від 1 до 10. Припустимо, якщо $\mathrm{K}_{\text {гтз }}=0$, то організація й технологія виробництва не мають додаткових резервів у життєвому циклі П-ОБ, якщо $\mathrm{K}_{\text {гтз }}=1-$ технологія має гнучкість $\mathrm{i}$ ефективно реагує на всі зміни $[4,6]$.

При цьому гнучкість повинна розглядатися не тільки як показник, а й як властивість, притаманна проектуванню будівельної технології системи, в якій відбуваються зміни: переходи з даного стану в інший при зведенні ВБНП та монтажі технологічного обладнання в КБВ, агрегованого у функціональні блоки, та характеризує ії здатність реагувати на численні внутрішні та зовнішні впливи виробничого середовища та модулів промислово-будівельних формувань щодо створення різних видів та груп блоків обладнання.

Зміна рівня гнучкості відображатиметься в різниці таких основних показників організаційно-технологічних модулів, як витрати праці, часу, ресурсів, терміни, вартість при реалізації систем технологій (методів та засобів) зведення та подальших перебудов П-ОБ на етапах та стадіях життєвого циклу в еволюції їх розвитку та деградації (реконструкція, модернізація, виведення з експлуатації та ліквідація).

Принципова особливість та своєрідність монтажно-технологічних вимог до проектування промислових об'єктів (ВБНП) підприємств хімічної галузі в КБВ полягає в тому, що проектувальний процес розбивається на два самостійних потоки (етапи): проектування агрегованих блоків на основі типових технологічних схем та вузлів та проектування будівлі ВБНП із комплектних будівельно-технологічних блоків.

Зазначена особливість процесу проектування ВБНП-КБВ має важливе значення при системному моделюванні об'єкта. Так, при розгляді будівлі як системи, а процесу проектування як розв'язання цієї системи, ієрархічна структура системи «промисловий об'єкт» (ВБНП) хімічної галузі у традиційному поелементному виконанні має три основні рівні П-ОБ: технологічна установка, виробництво та підприємство, а при КБВ наявність додаткової структурної одиниці П-ОБ об'єкта - блоку передбачає вже чотири ієрархічні рівні: комплектно-блоковий пристрій (блок), технологічна установка, виробництво, підприємство.

Особливість моделювання ВБНП у комплектно-блочному виконанні полягає в тому, що весь процес проектування характеризується поділом провідної ролі технологічного проектування при розробці проектних 
рішень блоків (АТК) в комплексі об'ємно-конструктивного компонування (ОКК) та архітектурно-будівельного (АБК) при розробці проектних рішень ВБНП виробництв та підприємства в цілому. Тим самим встановлюється чітка послідовність проектування технологічної як первинної та архітектурно-будівельної як вторинної частин об'єкта.

3 урахуванням виконаних класифікацій технічних рішень блоків визначено характеристики чотирьох класів блоків, типи та види блоків, ярусність та режим експлуатації та варіанти конструктивно-монтажних та апаратурно-планувальних рішень блоків хімічних виробництв, а також найважливішого просторового елемента ВБНП-КБВ - технічного коридору як елементу формуючого об'єкт та його нормальне функціонування тощо $[9,10]$.

Проведений аналіз та оцінка результатів застосування модульних технологій комплектно-блочного, потоково-суміщеного та роздільного методів зведення ВБНП (одноповерхових великопрогонових будівель підприємств хімічної галузі з різними класифікаційними характеристиками за способами встановлення блоків (кранами (КБГ), способом «насування» $(\mathrm{CH})$ ) застосуванням транспортно-монтажних засобів (ТМЗ)) та варіантів організації виготовлення доставки та укрупнення блоків, що дозволило оцінити виявлені взаємозалежності між витратами праці, тривалістю та масою блоків $[3,7,9]$.

Для обробки систематизованих даних застосовувався регресійний аналіз, що дозволило у загальному вигляді сформувати наступні залежності:

$$
\begin{aligned}
& \mathrm{Q}=\mathrm{K}_{1} \mathrm{P}+\mathrm{B}_{1}+\mathrm{C}_{1}(\mathrm{n}-1) ; \\
& \mathrm{T}=\mathrm{K}_{2} \mathrm{Q}+\mathrm{B}_{2}+\mathrm{C}_{2}(\mathrm{n}-1)
\end{aligned}
$$

де $\mathrm{Q}$ - витрати на встановлення блоків;

$\mathrm{T}$ - час на встановлення блоків;

$\mathrm{P}$ - маса блоків;

n - кількість вузлів постачання в блоках;

$\mathrm{K}_{1}, \mathrm{~K}_{2}, \mathrm{C}_{1}, \mathrm{C}_{2}, \mathrm{~B}_{1}$ и $\mathrm{B}_{2}-$ коефіцієнти регресії (табл. 1)

Кількісні значення коефіцієнтів регресії отримано з урахуванням застосування методу Гаусса (метод найменших квадратів). Оцінка отриманих залежностей шляхом обчислення коефіцієнтів регресії, середньоквадратичних відхилень тощо, а також оцінка їx за табличними значеннями коефіцієнтів Фішера підтвердила правильність висунутої гіпотези.

Побудовані номограми дозволяють визначати витрати праці та тривалість встановлення блоків залежно від вагових параметрів блоків для різних способів їх встановлення та варіантів організації та формування блоків стосовно об'єктів-представників підприємств та виробництв хімічної галузі (рис. 1). 
Таблиця 1

Коефіцієнти та вільні члени регресії для визначення витрат праці та тривалості встановлення блоків

\begin{tabular}{|c|c|c|c|c|c|c|c|}
\hline \multirow[t]{2}{*}{$\begin{array}{c}\text { Способи } \\
\text { монтажу } \\
\text { блоків }\end{array}$} & \multirow[t]{2}{*}{$\begin{array}{l}\text { Варіанти організації } \\
\text { формування блоків }\end{array}$} & \multicolumn{4}{|c|}{$\begin{array}{c}\text { Значення } \\
\text { коефіцієнтів } \\
\text { регресії }\end{array}$} & \multicolumn{2}{|c|}{$\begin{array}{c}\text { Значення } \\
\text { вільних } \\
\text { членів } \\
\text { регресії }\end{array}$} \\
\hline & & $\mathrm{K}_{1}$ & $\mathrm{~K}_{2}$ & $\mathrm{C}_{1}$ & $\mathrm{C}_{2}$ & $\mathrm{~B}_{1}$ & $\mathrm{~B}_{2}$ \\
\hline \multirow{3}{*}{$\begin{array}{l}\text { За допомогою } \\
\text { кранового } \\
\text { обладнання }\end{array}$} & У заводських умовах & 0,62 & 0,08 & - & - & 34,66 & 6,70 \\
\hline & $\begin{array}{l}\text { На майданчиках } \\
\text { укрупнювальної } \\
\text { збірки }\end{array}$ & 0,89 & 0,15 & 39,79 & 9,17 & 1,93 & 0,85 \\
\hline & \begin{tabular}{|l|} 
На проектних \\
позначках
\end{tabular} & 0,68 & 0,11 & 39,25 & 9,00 & - & - \\
\hline \multirow{3}{*}{ Насувний } & У заводських умовах & 1,22 & 0,16 & - & - & 154,03 & 21,60 \\
\hline & $\begin{array}{l}\text { На майданчиках } \\
\text { укрупнювальної } \\
\text { збірки }\end{array}$ & 1,48 & 0,23 & 39,78 & 9,17 & 122,03 & 15,75 \\
\hline & $\begin{array}{l}\text { На проектних } \\
\text { позначках }\end{array}$ & 1,27 & 0,19 & 158,67 & 23,90 & - & - \\
\hline $\begin{array}{l}\text { За допомогою } \\
\text { TМЗ }\end{array}$ & У заводських умовах & 0,30 & 0,05 & - & - & 7,50 & 2,74 \\
\hline
\end{tabular}

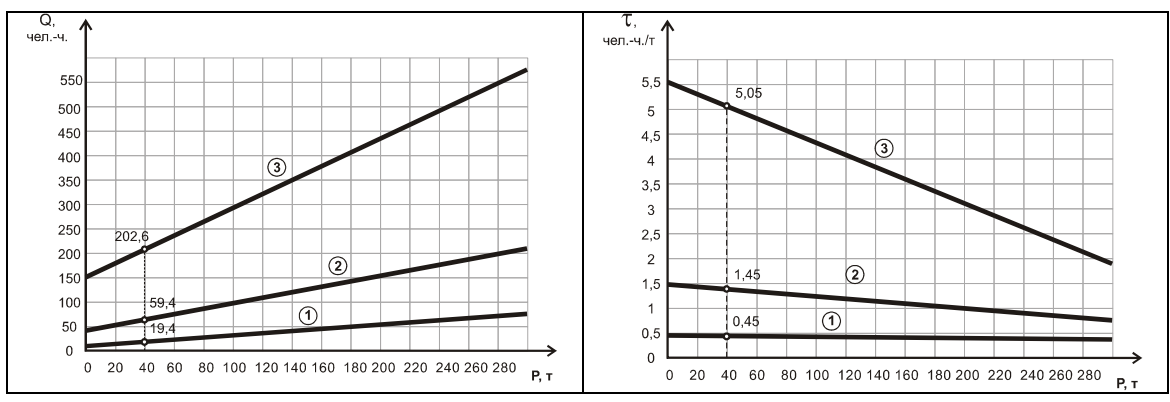

Рис. 1 - Діаграми залежності витрат праці (а) та питомих витрат праці (б) від маси агрегованих блоків для різних способів встановлення та варіантів організації їх формування: 1- монтаж блоків за допомогою транспортно-монтажних засобів; 2-монтаж блоків краном; 3- монтаж блоків способом «насування»

Зазначені специфічні особливості компонування ВБНП-КБВ підприємств хімічної галузі (установок, виробництв), що складаються 3 функціонально пов'язаних блокових та блочно-комплектних пристроїв 
(КБП), а також виконання будівельних та монтажних робіт, за їх модульним зведенням істотно впливають на прийняття організаційнотехнологічних рішень та викликають необхідність спеціального опрацювання економічних рішень у документах організаційноекономічної підготовки виробництва - проектів організації будівництва та проектів виконання робіт, що передбачають перенесення витрат праці з будівельного майданчика на машинобудівні підприємства виробники блоку 3 відповідними технічними та економічними обгрунтуваннями, що виконуються на стадії розробки ТЕО (ТЕР) (табл. 2).

Таблиця 2

Обгрунтування оптимального варіанта гнучкої модульної технології

\begin{tabular}{|c|c|c|c|c|c|}
\hline \multirow[b]{2}{*}{$\begin{array}{c}\text { Групи проектних } \\
\text { рішень об'єктів } \\
\text { представників }\end{array}$} & \multirow[b]{2}{*}{$\begin{array}{c}\text { Способи } \\
\text { монтажу } \\
\text { блоків }\end{array}$} & \multirow[b]{2}{*}{ 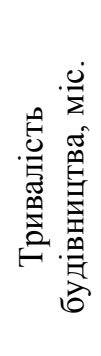 } & \multicolumn{3}{|c|}{ Економічна ефективність * } \\
\hline & & & 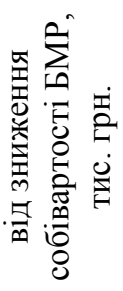 & 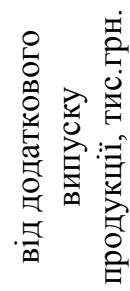 & 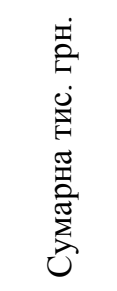 \\
\hline 1 & 2 & 3 & 4 & 5 & 6 \\
\hline \multirow{3}{*}{$\begin{array}{c}\text { ВБНП с } \\
\text { расположением } \\
\text { КБП на позначці } \\
\pm 0,00\end{array}$} & КБГ & 30 & 32,89 & 382,03 & 414,92 \\
\hline & $\mathrm{CH}$ & 31 & 25,81 & 309,24 & 335,05 \\
\hline & TM3 & 27 & 54,00 & 609,41 & 663,41 \\
\hline \multirow{3}{*}{$\begin{array}{c}\text { Відкриті } \\
\text { майданчики } 3 \\
\text { розташуванням } \\
\text { КБП на пзначці } \\
\pm 0.00\end{array}$} & КБГ & 24 & 72,78 & 836,81 & 909,59 \\
\hline & $\mathrm{CH}$ & 24,5 & 70,43 & 800,41 & 870,84 \\
\hline & TM3 & 12,5 & 150,22 & 1709,16 & 1860,19 \\
\hline
\end{tabular}

*) за узагальненими даними ТОВ «ПРОМХІММОНТАЖ»

(м. Сєвєродонецьк)

Різноманітність варіантів оснащеності будівельних та монтажних організацій вантажопідйомними машинами, заводської готовності та технологічності встановлення блоків у проектне положення та засобами доставки блоків, а також різні умови організації та розташування будівельних майданчиків та виконання робіт, модульної технології зведення ВБНП-КБВ підприємств хімічної галузі визначають можливість 
багатоваріантної потоково-суміщеною

промислово-будівельною організацією методів будівництва цих об'єктів.

Висновки. 1. Вибір раціонального варіанту гнучкої модульної технології може здійснюватися за критерієм міні-максу: мінімуму витрат праці на встановлення, випробування та пуско-налагоджувальний цикл блочно-комплектних пристроїв у проектне положення за рахунок максимальної потоково-сумісної організації методів промисловобудівельного виробництва, принципів цільового агрегування технологічних процесів, організаційних структур та функцій управління.

2. Останні можуть бути реалізовані шляхом: перетворення ВБНПКБВ на об'єктні потоки-комплекти транспортабельних блоків обладнання та конструкцій будівель; створення на стику двох галузей машинобудівної та будівельної - промислово-будівельних формувань (корпорацій, концернів) з комплектно-блочної споруди П-ОБ з високим ступенем мобільності, орієнтовані на кінцеву мету - введення в експлуатацію («під ключ» або «під потужність») об'єктів, що будуються 3 проектними характеристиками життєдіяльності та життєздатності П-ОБ.

\section{References}

1. Abaryikov V.P. Optimizatsiya sistemyi proektirovaniya $\mathrm{v}$ stroitelstve./ Abaryikov V.P. - M.: Izd.dom Graal, 2000. - 321 s.

2. Bulgakov S.N. Tehnologicheskie innovatsii $\mathrm{v}$ investitsionno-stroitelnom komplekse. - M.: RAASN, 1998. $-547 \mathrm{~s}$.

3. Metodicheskie rekomendatsii po razrabotke organizatsionno-tehnologicheskih resheniy v sostave POS i PPR dlya ob'ektov v komplektno-blochnom ispolnenii.- M.: TsNIIOMTP, 1999. - $72 \mathrm{~s}$.

4. Oleynik P.P. Organizatsiya stroitelstva. Kontseptualnyie osnovyi, modeli i metodyi, informatsionno-inzhenernyie sistemyi./ Oleynik P.P. - M.: Izd-vo «Profizdat», 2001. $-408 \mathrm{~s}$.

5. Systemy tekhnolohii zhyttievoho tsyklu investytsiino-budivelnoi sfery diialnosti/ Tian R.B., Uvarov P.Ye., Shparber M.Ye. Pryliepova M.O., y dr.// Prydniprovska derzhavna akademiia budivnytstva ta arkhitektury. Navch. posibnyk. -Dnipropetrovsk: Vydavnytstvo Makovetskyi Yu.V., 2010. - 344 s.

6. Uvarov P.E. Tekhnycheskyi prohress y dynamycheskaia adaptatsyia $\mathrm{v}$ teoryy y praktyke systemnoho proektyrovanyia proyzvodstvennukh zdanyi novoho pokolenyia. // Vestnyk KhHPU \#93 «Tekhnycheskyi prohress y effektyvnost proyzvodstva». Kharkov: KhHPU, 2000. - S. 144-150.

7. Uvarov P.Ye. Pryntsypy intehrovanoho orhanizatsiino-tekhnolohichnoho proektuvannia investytsiino-budivelnoi diialnosti.: Avtoreferat dysertatsii na zdobuttia naukovoho stupenia kandydata tekhnichnykh nauk: 05.23.08 / P. Ye. Uvarov. Dnipropetrovsk., 2008. - $31 \mathrm{~s}$.

8. Uvarov P.E. Modelirovanie organizatsionno-ekonomicheskih resheniy investitsionno-stroitelnyih proektov $\mathrm{i}$ ih inzhenernoe soprovozhdenie / Uvarov P.E., Prilepova M.A., Shparber M.E., Tyan E.R. // VIsnik DonbaskoYi natsIonalnoYi akademIYi budIvnitstva I arhItekturi. - 2010 - \#2010-3(83) - S. 71-79 
9. Cherepov I.A., Alekseev S.V., Konstantinova E.P. Proektirovanie promyishlennyih ob'ektov $\mathrm{v}$ komplektno-blochnom ispolnenii (obzor). - M.: VNIIIS, 1987. $-59 \mathrm{~s}$.

10. Elyash M.L., Marshev V.Z. Tehnologiya komplektno-blochnogo montazha oborudovaniya. -M.: Stroyizdat, 1994. -204 s.

\section{Список використаної літератури}

1. Абарыков В.П. Оптимизация системы проектирования в строительстве./ Абарыков В.П. - М.: Изд.дом Грааль, 2000. - 321 с.

2. Булгаков С.Н. Технологические инновации в инвестиционно-строительном комплексе. - М.: РАACH, 1998. - 547 с.

3. Методические рекомендации по разработке организационнотехнологических решений в составе ПОС и ППР для объектов в комплектноблочном исполнении.-М.: ЦНИИОМТП, 1999. - 72 с.

4. Олейник П.П. Организация строительства. Концептуальные основы, модели и методы, информационно-инженерные системы./ Олейник П.П. - М.: Издво «Профиздат», 2001. - 408 с.

5. Системи технологій життєвого циклу інвестиційно-будівельної сфери діяльності/ Тян Р.Б., Уваров П.Є., Шпарбер М.Є. Прилєпова М.О., и др.// Придніпровська державна академія будівництва та архітектури. Навч. посібник. Дніпропетровськ: Видавництво Маковецкий Ю.В., 2010. - 344 с.

6. Уваров П.Е. Технический прогресс и динамическая адаптация в теории и практике системного проектирования производственных зданий нового поколения. // Вестник ХГПУ №93 «Технический прогресс и эффективность производства». Харьков: ХГПУ, 2000. - С. 144-150.

7. Уваров П.Є. Принципи інтегрованого організаційно-технологічного проектування інвестиційно-будівельной діяльності.: Автореферат дисертації на здобуття наукового ступеня кандидата технічних наук: 05.23.08 / П. Є. Уваров. Дніпропетровськ., 2008. - 31 с.

8. Уваров П.Е. Моделирование организационно-экономических решений инвестиционно-строительных проектов и их инженерное сопровождение / Уваров П.Е., Прилепова М.А., Шпарбер М.Е., Тян Е.Р. // Вісник Донбаської національної академії будівництва і архітектури. - 2010 - №2010-3(83) - С. 71-79

9. Черепов И.А., Алексеев С.В., Константинова Е.П. Проектирование промышленных объектов в комплектно-блочном исполнении (обзор). - М.: ВНИИИС, 1987. - 59 с.

10. Эльяш М.Л., Маршев В.3. Технология комплектно-блочного монтажа оборудования. -М.: Стройиздат, 1994. - 204c. 